$\xi=-1$

\title{
Groundwater Quality Assessment for Irrigation in Madhavaram
}

\author{
D. Sivakumar ${ }^{1 *}$, S. Govindasami ${ }^{2}$, B. Raghul Raj $^{3}$, C. Gowdham ${ }^{4}$, V.M. $\operatorname{Ragothaman~}^{5}$ \\ 1,2,3,4,5 Department of Civil Engineering, \\ Vel Tech High Tech Dr.Rangarajan Dr.Sakunthala Engineering College, Avadi, Chennai, Tamil Nadu, India \\ *Corresponding author E-mail:shri.sivakumar1974@gmail.com
}

\begin{abstract}
The study focused to assess the groundwater in Madhavaram, Chennai, Tamil Nadu, for irrigational purposes. Irrigation indices like SAR, SSP, PI and KR was determined in each groundwater sample to identify its irrigational suitability. This study further envisaged that these groundwater aquifers have low Sodium adsorption ratio and hence groundwater is fit for irrigation, while residual sodium bicarbonate and Kelly's ratio values indicated that majority of these aquifer have water of marginal to harmful quality against irrigation. The dominance pattern of cations in the studied ground water was in the order of $\mathrm{Na}>\mathrm{Ca}>\mathrm{Mg}>\mathrm{K}$ and the sequence of anionic dominance was as follows: $\mathrm{Cl}>\mathrm{HCO}_{3}>\mathrm{SO}_{4}$. All 20 wells fall under the excellent category of SAR. SSP values of groundwater range from 49 to 71 and indicated that 15 wells are under permissible and 5 wells are under doubtful classification. PI value indicated that groundwater is unsuitable against irrigation. The KR indicated that groundwater quality in 18 wells is not fit for irrigation. Hence, necessary pre-treatment methodology is to be adopted for utilizing groundwater for irrigation purpose.
\end{abstract}

Keywords: Groundwater; Urban Pollution; Physico-chemical parameters; Irrigation Indices

\section{Introduction}

Water resource scarcity was observed in many part of world because of highly contamination by various industrial discharges to the land and nearby water bodies. Along with the natural surface water resources, groundwater is used to serve various purposes like domestic uses, agricultural uses and industrial uses. But due to over population demand, industrial growth, groundwater gets polluted.

Groundwater quality depends on surface water, subsurface water and geology of soil. The change in quality of groundwater affects the all living beings particularly human health. The geochemical parameters in groundwater also affect the quality of groundwater, and hence, it is necessary to assess the groundwater quality in terms of various geochemical parameters before it is used for domestic, agricultural and industrial uses.

Arshid Jehangir [1] studied the geochemistry parameters and irrigation quality indices for water along Jhelum river. Irrigation indices were calculated for irrigation purposes in Bapatla was studied by Devojee [2]. The drinking and irrigation suitability of groundwater in Pugalur, TN was studied by Jafar [3].

Krishnakumar [4] focused the groundwater in Vedaraniyam for its suitability for irrigation. The water quality parameters for surface water and groundwater in Bargarh were determined by Mahananda againt the suitability of irrigation [5]. Nag [6] used GIS to assess gruondwaer quality for both domestic and irrigation uses in Birbhum District, West Bengal, India. Sinha [7 assessed groundwater quality for irrigation in a hard rock hilly terrain using GIS and suitability of groundwater for Irrigation in Pulicat using GIS also studied by Sivakumar [8].

Groundwater quality is not only pollution by urbanization, but also polluted due to industrialization. In this aspect, suitability of groundwater around Pallavaram, tannery industry belt, Chennai was studied by Sivakumar [9, 10].

Thus, this project mainly focused to investigate the groundwater quality to suit irrigation purposes in Madhavaram, Chennai. The objectives framed for this study are assessing physico-chemical quality parameters in groundwater of Madhavaram and finding the groundwater utilization for irrigation with the help of irrigation indices viz., SAR, SSP, PI and KR.

\section{Methods and Materials}

\subsection{Study Area}

The study area is Madhavaram and it is a Taluk located between Perambur and Kodungaiyur in North Chennai, Tamil Nadu. The latitude and longitude of Madhavaram is 13.14 and 80.23 respectively. The satellite image of Madhavaram is shown in Fig. 1.

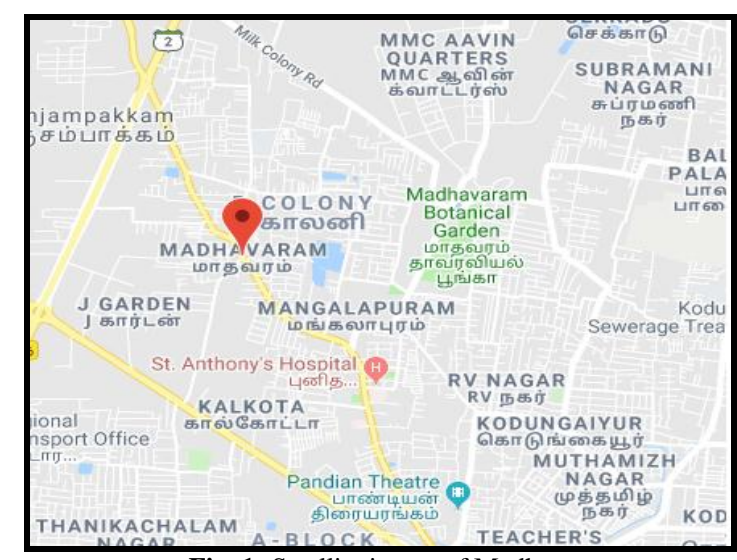

Fig. 1: Satellite image of Madhavaram 


\subsection{Collection of Groundwater Samples}

The sterilized bottles used for collecting bore well water samples. The 20 bore well water samples collected and were analyzed against basic water quality parameters as per APHA, 2005. The latitude and longitude of 20 bore wells are presented in Table 1.

Table 1: Latitude and longitude details of the sites

\begin{tabular}{|c|c|c|}
\hline Well No & Latitude & Longitude \\
\hline w1 & 13.11783 & 80.20350 \\
\hline w2 & 13.11800 & 80.19600 \\
\hline w3 & 13.14305 & 80.24019 \\
\hline w4 & 13.15250 & 80.24789 \\
\hline w5 & 13.15654 & 80.23410 \\
\hline w6 & 13.14122 & 80.19848 \\
\hline w7 & 13.15141 & 80.20490 \\
\hline w8 & 13.14908 & 80.21990 \\
\hline w10 & 13.14780 & 80.24650 \\
\hline
\end{tabular}

Table 2: Physico-chemical parameters of 20 bore well samples

\begin{tabular}{|c|c|c|c|c|c|c|c|c|c|c|c|c|c|c|}
\hline Wells & $\mathrm{EC}$ & $\mathrm{pH}$ & $\mathrm{Ca}$ & $\mathrm{Mg}$ & $\mathrm{Na}$ & $\mathrm{K}$ & $\mathrm{HCO}_{3}$ & $\mathrm{SO}_{4}$ & Chloride & Nitrate & Fluoride & TDS & $\begin{array}{c}\mathrm{TH} \\
\left(\mathrm{CaCO}_{3}\right) \\
\end{array}$ & \begin{tabular}{|c|} 
Total \\
Alkalinity
\end{tabular} \\
\hline 1 & 3830 & 7.1 & 88 & 182 & 433 & 3 & 580 & 10 & 922 & 9 & 1 & 2032 & 970 & 475 \\
\hline 2 & 850 & 7.2 & 38 & 22 & 110 & 0 & 275 & 40 & 121 & 4 & 1 & 473 & 185 & 225 \\
\hline 3 & 2520 & 6.4 & 74 & 41 & 413 & 5 & 336 & 151 & 549 & 35 & 0 & 1436 & 355 & 275 \\
\hline 4 & 1040 & 5.9 & 68 & 16 & 131 & 0 & 195 & 69 & 149 & 102 & 0 & 633 & 235 & 160 \\
\hline 5 & 1560 & 6.4 & 86 & 39 & 177 & 16 & 122 & 66 & 340 & 169 & 0 & 949 & 375 & 100 \\
\hline 6 & 2138 & 6.9 & 67 & 79 & 217 & 4 & 959 & 48 & 467 & 38 & 0 & 1175 & 495 & 293 \\
\hline 7 & 2007 & 6.6 & 72 & 63 & 255 & 6 & 298 & 65 & 433 & 69 & 0 & 1131 & 441 & 244 \\
\hline 8 & 1883 & 6.5 & 77 & 48 & 248 & 9 & 240 & 81 & 402 & 99 & 0 & 1091 & 390 & 196 \\
\hline 9 & 1448 & 6.1 & 71 & 25 & 204 & 2 & 227 & 88 & 263 & 89 & 0 & 864 & 279 & 187 \\
\hline 10 & 2356 & 6.9 & 70 & 91 & 287 & 4 & 383 & 46 & 525 & 35 & 0 & 1287 & 550 & 314 \\
\hline 11 & 2158 & 6.6 & 74 & 65 & 285 & 6 & 314 & 75 & 470 & 63 & 0 & 1214 & 452 & 257 \\
\hline 12 & 2123 & 6.5 & 75 & 50 & 304 & 6 & 292 & 99 & 456 & 68 & 0 & 1212 & 393 & 239 \\
\hline 13 & 2286 & 6.4 & 74 & 41 & 358 & 5 & 306 & 130 & 492 & 53 & 0 & 1311 & 357 & 251 \\
\hline 14 & 2217 & 6.3 & 74 & 39 & 348 & 5 & 301 & 129 & 471 & 55 & 0 & 1270 & 344 & 246 \\
\hline 15 & 2553 & 7.1 & 69 & 110 & 299 & 2 & 435 & 29 & 578 & 16 & 1 & 1373 & 624 & 356 \\
\hline 16 & 2969 & 7.1 & 75 & 132 & 344 & 3 & 479 & 25 & 690 & 16 & 1 & 1588 & 733 & 392 \\
\hline 17 & 2377 & 6.8 & 73 & 85 & 299 & 4 & 369 & 58 & 529 & 44 & 0 & 1309 & 532 & 301 \\
\hline 18 & 2263 & 6.6 & 73 & 71 & 299 & 5 & 338 & 74 & 496 & 53 & 0 & 1262 & 472 & 276 \\
\hline 19 & 3040 & 7.0 & 77 & 136 & 352 & 3 & 486 & 25 & 709 & 16 & 1 & 1626 & 751 & 398 \\
\hline 20 & 2473 & 6.8 & 73 & 93 & 307 & 4 & 389 & 53 & 554 & 38 & 0 & 1354 & 564 & 318 \\
\hline
\end{tabular}

\subsection{Physico-Chemical Analysis}

From Table 2, it may be noted that the $\mathrm{pH}$ values of the groundwater varied from 5.9 to 7.1 indicates that neutral quality of groundwater, and hence, it may be used for all purposes.

The TDS values were ranged between 473 and $1626 \mathrm{mg} / \mathrm{l}$ indicated that the TDS was contributed by sewage discharges. The EC values were varied between 850 and $3830 \mu \mathrm{S} / \mathrm{cm}$. The average value of EC found in this study area is $2204.5 \mu \mathrm{S} / \mathrm{cm}$, indicated that more dispersible ions are presented in the groundwater because of geology of earth crust along with improper disposal of wastewater on land. The total hardness value ranged between 185 and $970 \mathrm{mg} / \mathrm{l}$. The average total hardness value found to be 74.82 $\mathrm{mg} / \mathrm{l}$. Calcium concentration varied from $38 \mathrm{mg} / \mathrm{l}$ to $88 \mathrm{mg} / \mathrm{l}$. The concentration of magnesium in 20 bore well water ranged between 22 and $182 \mathrm{mg} / \mathrm{l}$. The concentration of sodium in groundwater varied from 110 to $433 \mathrm{mg} / \mathrm{l}$. Potassium values reached to 16 from $0 \mathrm{mg} / \mathrm{l}$. Bicarbonate values in 20 bore wells varied from 122 to $959 \mathrm{mg} / \mathrm{l}$. The average value of bicarbonate found in the study area is $366.18 \mathrm{mg} / \mathrm{l}$. The concentration of sulphate varied between 10 and $151 \mathrm{mg} / \mathrm{l}$ with an average of $68.02 \mathrm{mg} / \mathrm{l}$. The chloride concentration were found between 121 and $922 \mathrm{mg} / \mathrm{l}$ with an average of $480.82 \mathrm{mg} / \mathrm{l}$. Nitrate concentration is found from 4 to $169 \mathrm{mg} / \mathrm{l}$ with an average of $53.45 \mathrm{mg} / \mathrm{l}$. Fluoride concentration was established from 0 to $1 \mathrm{mg} / \mathrm{l}$. Total alkalinity ranged from 100 to 475 $\mathrm{mg} / \mathrm{l}$. The average alkalinity of this study area is $275.262 \mathrm{mg} / \mathrm{l}$.

\begin{tabular}{|c|l|l|}
\hline w11 & 13.13655 & 80.21983 \\
\hline w12 & 13.13624 & 80.22776 \\
\hline w13 & 13.13833 & 80.23559 \\
\hline w14 & 13.13893 & 80.24511 \\
\hline w15 & 13.12822 & 80.20347 \\
\hline w16 & 13.12399 & 80.20936 \\
\hline w17 & 13.12981 & 80.21848 \\
\hline w18 & 13.12762 & 80.22518 \\
\hline w19 & 13.11930 & 80.21210 \\
\hline w20 & 13.12019 & 80.22251 \\
\hline
\end{tabular}

\section{Results and Discussion}

The parameters $\mathrm{pH}$, total dissolved solids, total hardness, calcium, magnesium, chloride, sulphate, nitrate, fluoride, sodium, total alkalinity, bicarbonate and potassium were analysed in the 20 bore wells water around Madhavaram. Table 2 represents the various parameters in groundwater samples from 20 sites.
All values are indicating the quality of groundwater collected from 20 wells.

\subsection{Irrigation Water Quality Indices}

Various irrigation indices like sodium adsorption ratio (SAR), soluble sodium percentage (SSP), and permeability index (PI) are important indices along with Kelley's ratio (KR) to judge the groundwater against irrigation. The results of SAR, SSP, PI and $\mathrm{KR}$ are presented in Table 3.

Table 3: The results of SAR, SSP, PI and KR for 20 bore wells of groundwater in Madhavaram

\begin{tabular}{|c|c|c|c|c|}
\hline Well No. & SAR & SSP & PI & KR \\
\hline 1 & 6.02 & 49.14 & 101.00 & 0.96 \\
\hline 2 & 3.50 & 56.16 & 111.30 & 1.28 \\
\hline 3 & 9.52 & 71.76 & 102.67 & 2.52 \\
\hline 4 & 3.70 & 54.61 & 106.80 & 1.2 \\
\hline 5 & 3.96 & 51.78 & 101.89 & 1.02 \\
\hline 6 & 4.22 & 48.82 & 109.25 & 0.94 \\
\hline 7 & 5.26 & 55.85 & 103.18 & 1.25 \\
\hline 8 & 5.45 & 58.39 & 102.97 & 1.38 \\
\hline 9 & 5.31 & 61.54 & 104.52 & 1.59 \\
\hline 10 & 5.30 & 53.13 & 102.85 & 1.13 \\
\hline 11 & 5.81 & 57.97 & 102.94 & 1.36 \\
\hline 12 & 6.64 & 62.82 & 102.94 & 1.67 \\
\hline 13 & 8.23 & 68.69 & 102.83 & 2.17 \\
\hline 14 & 8.15 & 68.86 & 102.94 & 2.19 \\
\hline 15 & 5.18 & 50.92 & 102.66 & 1.03 \\
\hline
\end{tabular}




\begin{tabular}{|l|l|l|l|l|}
\hline 16 & 5.50 & 50.40 & 101.98 & 1.01 \\
\hline 17 & 5.61 & 54.96 & 102.73 & 1.21 \\
\hline 18 & 5.95 & 57.89 & 102.86 & 1.36 \\
\hline 19 & 5.56 & 50.36 & 101.88 & 1.01 \\
\hline 20 & 5.60 & 54.17 & 102.63 & 1.17 \\
\hline
\end{tabular}

\subsubsection{Sodium Adsorption Ratio (SAR)}

SAR determines the cation exchange property of soil with water. It affects the soil structure when sodium is replace with calcium and magnesium. SAR by calculated by

$\mathrm{SAR}=\mathrm{Na}^{+} /\left[\left(\mathrm{Ca}^{2+}+\mathrm{Mg}^{2+}\right) / 2\right]^{0.5}$

SAR value is unit less however, the parameter values are substituted in meq/l. Classification of 20 bore wells water sample against SAR is presented in Table 4.

Table 4: SAR values classification of groundwater (Todd 1959; Richards 1954)

\begin{tabular}{|l|c|c|}
\hline Water Quality Type & SAR Values & No of Samples \\
\hline Excellent & $<10$ & 20 \\
\hline Good & $10-18$ & 0 \\
\hline Doubtful & $18-26$ & 0 \\
\hline Unsuitable & $>26$ & 0 \\
\hline
\end{tabular}

\subsubsection{Soluble Sodium Percentage (SSP)}

SSP indicates the availability of sodium in groundwater which increases the hardness and permeability of soil for plants growth. It can be calculated by

$\mathbf{S S P}=[(\mathrm{Na}+\mathrm{K}) /(\mathrm{Ca}+\mathrm{Mg}+\mathrm{Na}+\mathrm{K})] \times 100$

where, all parameters are expressed in meq/l.

The water quality classification of 20 bore wells water based on SSP is presented in Table 5 .

Table 5: SSP classification of groundwater

\begin{tabular}{|l|c|c|}
\hline \multicolumn{1}{|c|}{ Water Quality Type } & SSP Values & No of Samples \\
\hline Excellent & $<20$ & 0 \\
\hline Good & $20-40$ & 0 \\
\hline Permissible & $40-60$ & 15 \\
\hline Doubtful & $60-80$ & 5 \\
\hline Unsuitable & $>80$ & 0 \\
\hline
\end{tabular}

All 20 wells are excellent category according to SAR Values. From all the study sites had very low SAR values, which ranged between 5 and 10, indicating that groundwater samples had excellent quality against irrigation. The SSP values found for the groundwater collected in Madhavaram study area varied from 49 to 72, of which, SSP values in 15 sites found between 40 and 60 . According to Todd, all 15 sites belong to permissible category except 5 sites $(3,9,12,13$, and 14) which belong to doubtful category. Low SAR and SSP seemed to be due to significant quantities of divalent calcium and magnesium.

\subsubsection{Wilcox Diagram}

Wilcox diagram was arrived using the values of SSP and EC. The Wilcox diagram is shown in Fig. 2. Wilcox diagram specified that groundwater samples fell under the "Good to permissible" and "doubtful to unsuitable" categories. The Wilcox classification for the groundwater of 20 bore wells is presented in Table 6 .

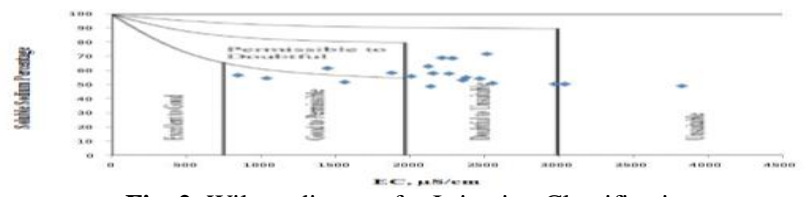

Fig. 2: Wilcox diagram for Irrigation Classification
Table 6: Wilcox diagram observation

\begin{tabular}{|l|c|l|}
\hline Water Quality & $\begin{array}{l}\text { SSP } \\
\text { Values }\end{array}$ & $\begin{array}{l}\text { No of Samples } \\
\text { (Wilcox Observations) }\end{array}$ \\
\hline Excellent & $<20$ & 0 \\
\hline Good & $20-40$ & $3(\mathrm{~W} 2, \mathrm{~W} 4, \mathrm{~W} 5)$ \\
\hline Permissible & $40-60$ & $2(\mathrm{~W} 9, \mathrm{~W} 8)$ \\
\hline Doubtful & $60-80$ & $\begin{array}{l}13(\mathrm{~W} 3, \mathrm{~W} 6, \mathrm{~W} 7, \mathrm{~W} 10, \mathrm{~W} 11, \mathrm{~W} 12, \\
\text { W13, W14, W15, W16, W17, W18, } \\
\text { W20) }\end{array}$ \\
\hline Unsuitable & $>80$ & $2(\mathrm{~W} 1, \mathrm{~W} 19)$ \\
\hline
\end{tabular}

\subsubsection{Permeability Index (PI)}

Permeability of soil is affected by occurrence of various ions like $\mathrm{Na}^{+}, \mathrm{Ca}^{2+}, \mathrm{Mg}^{2+}$ and $\mathrm{HCO}_{3}$ contents. Hence, it is necessity to calculate permeability index against irrigation. It can be determined by

$\mathrm{PI}=\left(\mathrm{Na}^{+}+\sqrt{ } \mathrm{HCO}_{3}\right) \times 100 /\left(\mathrm{Ca}^{2+}+\mathrm{Mg}^{2+}+\mathrm{Na}^{+}+\mathrm{K}^{+}\right)$

The PI values ranged between 101 and 105 (Table 3). The values of PI indicated that all 20 groundwater bore wells come under the category of class III and indicted groundwater is not suited for irrigation (Table 7).

Table 7: PI classification of groundwater (Gupta and Gupta, 1987)

\begin{tabular}{|l|c|c|}
\hline \multicolumn{1}{|c|}{ Water Quality Type } & PI Values & No of Samples \\
\hline Suitable for irrigation & $<80$ & 0 \\
\hline Moderate for irrigation & $80-100$ & 0 \\
\hline Unsuitable for irrigation & $>100$ & 20 \\
\hline
\end{tabular}

\subsubsection{Kelly's Ratio (KR)}

Kelly's Ratio (KR) used to know the availability of calcium and magnesium against sodium. If $\mathrm{KR}<1$, water is used for irrigation and $>1$ indicates not suitable for irrigation. KR is determined by

$\mathrm{KR}=\mathrm{Na} /(\mathrm{Ca}+\mathrm{Mg})$

where, all parameters in meq/l.

Table 8: KR classification of groundwater

\begin{tabular}{|l|c|c|}
\hline \multicolumn{1}{|c|}{ Water Quality Type } & KR Values & No of Samples \\
\hline Suitable for Irrigation & $<1$ & 2 \\
\hline Not Suitable for Irrigation & $>1$ & 18 \\
\hline
\end{tabular}

The KR showed that water quality in 18 bore well samples are not suitable and only 2 bore wells are suitable for irrigation (Table 8 ).

\section{Conclusions}

The groundwater quality of Madhavaram, Chennai, Tamil Nadu was assessed for irrigation. The irrigation quality indices were calculated based on calcium, magnesium, potassium, sodium and bicarbonate. Groundwater from most of the bore wells was found very hard in nature, because of availability of more calcium, magnesium and sodium. All the 20 wells fall under the excellent category of SAR. The SSP values of groundwater indicated that most of bore wells were not suited for irrigation. The Wilcox diagram indicated that the groundwater quality fell under "Good to permissible" and "doubtful to unsuitable" categories. PI values represented that groundwater in Madhavaram can be labeled as a class III (100-120\%) and showed that water from bore wells are unsuited against irrigation. The Kelly's ratio showed that water quality in 18 wells is not suitable for irrigation. Hence, it is necessary to adopt some pre-treatment methodology for utilizing groundwater for irrigation purpose. 


\section{Acknowledgement}

The Authors express their gratitude to the Management of Vel Tech High Tech Dr.Rangarajan Dr.Sakunthala Engineering College, Avadi, Chennai, Tamil Nadu, India, for their support to complete this project successfully.

\section{References}

[1] Arshid J, Aasimah T, \& Yousuf AR, "Geochemistry and irrigation quality of groundwater along river Jhelum in South Kashmir, India", Recent Research in Science and Technology, 2011, Vol. 3, No. 6, 57-63.

[2] Devojee B, Nagababu G, Manoj Kumar M, Nandini Y \& Hemakumar HV, "Assessment and Mapping of Irrigation Water Quality Index of Bapatla Mandal, Guntur District, Andhra Pradesh, India", International Journal of Current Microbiology and Applied Sciences, 2018, Vol. 7, No. 1, 1914-1920.

[3] Jafar AA, Loganathan K \& Ananthakrishnan, "A comparative evaluation of groundwater suitability for drinking and irrigation purposes in Pugalur area, Karur District, Tamilnadu, India", Archives of Applied Science Research, 2013, Vol. 5, No. 1, 213-223.

[4] Krishnakumar P, Lakshumanan C, Pradeep Kishore V, Sundararajan M, Santhiya G \& Chidambaram S, "assessment of groundwater quality in and around Vedaraniyam, South India", Environmental Earth Sciences, 2014, Vol. 71, No. 5, 2211-2225.

[5] Mahananda M.R, Mohanty B.P. and Behera Mahananda N.R. Physico-Chemical Analysis of Surface and Ground Water of Bargarh District, Orissa, India, IJRRAS, 2010, Vol. 2, No. 3, 284-295.

[6] Nag, S.K and Shreya Das Groundwater Quality For Irrigation And Domestic Purposes - A GIS Based Case Study Of Suri I And II Blocks, Birbhum District, West Bengal, India", International Journal of Advancement in Earth and Environmental Sciences, Vol.2, No.1, 25-38

[7] Sinha AK, Vinay K, \& Singh PK, "GIS Approach based Groundwater Quality Assessment and Evaluation for Irrigation Purpose in a Hard Rock Hilly Terrain of Western India”, International Journal of Current Microbiology and Applied Sciences, 2018, No. 7, 13131332 .

[8] Sivakumar D, Abraham Daniel Raj P, Arivoli E, \& Hemalatha M, "Groundwater Suitability for Irrigation in Pulicat Using GIS", Journal of Chemical and Pharmaceutical Sciences, 2016, Vol. 09, No. 03, 1542-1549.

[9] Sivakumar D, Kandaswamy AN, Kalpana Priya V, \& Hemalatha $\mathrm{S}$, "Suitability of groundwater in and around Tannery industrial belt", Journal of Chemical and Pharmaceutical Sciences, 2015, Vol. 08, No. 02, 292-297.

[10] Sivakumar D, Thiruvengadam M, Anand R \& Ponpandian M "Suitability of groundwater around Pallavaram, Chennai, Tamil Nadu”, Pollution Research EM International, 2014, Vol. 33, No. 03 , 541-546. 